\title{
Study on the Reproduction of Labor Force Based on All-round Development of Human Beings
}

\author{
Hong Liu \\ Guangxi Technological College of Machinery and Electricity \\ Nanning, China 530007
}

\begin{abstract}
This paper studies the reproduction of labor force and all-round development of human beings from the perspective of all-round development of human beings, explores the relationship between college entrance examination and labor reproduction, explores the simple labor and complex labor, and analyzes the upgraded version of labor reproduction. For example, it analyzes the impact of labor reproduction on overall development of human beings after "Internet plus", "ideological and political education plus", "standard plus" and "3D printing plus". The new generation of reserve labor force in China is shaped into the generation of highly skilled and sophisticated workers with communistic belief.
\end{abstract}

Keywords-all-round development of human beings; labor force; the reproduction of labor force

\section{INTRODUCTION}

Marx believes that the all-round development of human beings is an inevitable requirement of large-scale industrial production. The method of cultivating all-round development of people is the combination of education and productive labor. Only in communist society, it can finally achieve allround development of human beings. Today, China has just completed the basic goal of the "three-step" strategy and started the journey of "Two Centenary Goals". Under the guidance of $\mathrm{Xi}$ Jinping's socialist ideology with Chinese characteristics in the new era, the people of the whole country have worked hard for building a modern and powerful socialist country. In this era of prosperity and development, it is of far-reaching significance to study the reproduction of labor force based on the all-round development of human beings.

\section{THE REPRODUCTION OF LABOR FORCE}

Labor force is an important component of socialized mass production. Labor force refers to the ability of workers to work, including the recovery, renewal and development of their physical and mental resources. The reproduction of labor force means the restoration, renewal and development of the physical and mental health of workers through constant consumption, including the continuous restoration, renewal and enhancement of the physical and mental capacities of the workers in the present generation as well as the continuous education, training and supplement of the new generation of labor force.
Tao Fuyuan and Jin Cheng argue that the all-round development of people includes the all-round development of human life, the all-round development of human capabilities, the all-round development of human social relations and the all-round development of human personality. The all-round development of human personality includes its unique, independent, creative and all-round development.

This paper argues that labor reproduction is based on the recovery, renewal and development of the physical and intellectual resources of all-round development of human beings, including stock labor reproduction and incremental labor reproduction and reserve labor reproduction. In order to achieve all-round development to the maximum extent, the labor force who joined the mass production of socialization would realize the restoration, renewal and development of the physical and intellectual resources and the daily maintenance of their families through the consumption data and continuous education. And it is stock labor force reproduction. In the term of incremental labor reproduction, the labor force that newly joined the largescale socialized production each year is equivalent to the total of the marginal labor force. The reserve labor force reproduction refers to the Cenozoic labor force from birth to employment. They need years of education, growth and training. And they would be the incremental labor. And then, they would become the stock labor force.

At present, general secretary $\mathrm{Xi}$ pointed out the imbalance in the development of productive forces in his summary of the major contradictions of socialism with Chinese characteristics in the new era. The potential labor productivity is different in China according to the differences of the means of production and the means of subsistence brought about by the regions and industries. In the rural areas, the potential reproductive labor force may inherit part of the share of rural collective land ownership and part of the contractual rights of family-owned land and part of rural house sites and real estate. The potential labor force is born in the city. And they can't inherit means of production. They only can hold the consumption data held by parents.

\section{THE RELATIONSHIP BETWEEN COLLEGE ENTRANCE} EXAMINATION AND THE REPRODUCTION OF LABOR FORCE

The college entrance examination is the continuation and development of the system of examinations for thousands of 
years in China. It inherits the unified threshold of the examination system for the people with different backgrounds. It provides the fair competition opportunities to select talents for the country. It is also an important part of labor reproduction. The college entrance examination will be linked with all the different kinds of colleges and universities. And it is also related to all the professions needed by politics, economy, culture and construction in China. College entrance examination is an unprecedented classification of incremental reproduction of the labor force and reserve reproduction of the labor force. After the college entrance examination, reserve reproduction of labor force would enter into different colleges and universities. And they would select the different professions. Then, they would learn professional knowledge for 3-4 years. As the saying goes, women are afraid to marry the wrong man, and the men are afraid to do the wrong job. After the college entrance examination, the most profound memory of the reserve reproductive labor force is to select the profession and choose the types of jobs.

The colleges and universities in China can be divided into research universities, applied undergraduate and higher vocational colleges. Each of the institutions has dozens to hundreds of professionals. The reserve reproductive labor force almost has no understanding of China's colleges and universities before the college entrance examination. In addition to the university's name, geographical location and outstanding alumni, they know nothing about the professional, knowledge, and skills. Therefore, the reserve reproductive labor force is complacent before the entrance examination. After the college entrance examination, they are unusually confused. How should colleges and universities face these confused backup reproductive labor force?

\section{A. All-round Developments of Human Beings and \\ Professional Cognition}

With the further development of division of labor in society, the old system of social division of labor is broken. The new social division of labor is being formed and constantly updated. The traditional occupation is disappearing. They carve up the cheese. How can the original labor have the transformation? How should the reproductive workforce develop and participate in continuing education? The most important issue is to develop the occupational cognition.

At present, the popular topic is supply-side reform. Why would it make the supply-side reform? The demand has changed. And the changes of the demands not only lead to supply-side reform. It is bound to lead to the changes of the composition of the means of production, the changes of production and the labor force, the reconstruction of skills structure and labor knowledge structure, and the changes of the composition of consumer data. How should the changes adapt to the specific needs of large-scale socialized production? How can we deal with the answer of this question? Professor Jiang Wenpei, vice president of Guangxi technological college of machinery and electricity, gives us the answer of the competition of college students' occupational cognition promoted by vocational colleges across the country. His approach is to give this task to university students of various majors. And I think his way is right.

College students would be the reserve reproductive workforce. And they must unlock their own imagined professional confusion. First, students should make the investigation of the employment of the specialty. It would know what jobs the graduates could do. Then, the students should put them out one by one.

After arranging the positions one by one, the students need to further investigate the specific work that needs to be done for each position. And then, the student should refine each work.

After that, what kinds of skills are required for each specific job?

What kind of expertise is needed to develop the skills for each specific job?

The composition of the professional knowledge corresponding to these skills should be taught by university teachers. The reformed teaching materials should be composed of these contents. Teachers should organize teaching materials according to this content, carry out education reform and impart knowledge to solve the problems for these students.

If every reform of professional education in universities and vocational colleges and curricular reforms are improved according to this concept, the nationally-trained reserve reproductive labor force would meet the needs of society. Even if they encounter new supply-side reforms after embarking on jobs, they would find jobs that need to be transformed in accordance with the vocational recognition methods learned in universities and vocational schools. And they would become workers with the needs of transformation. Then, they would study the skills what this job needs, and master the knowledge of the skills. Afterwards, we should transmit the reform information to the teachers who are carrying out the curriculum reform in universities and vocational colleges. And then, the materials they compile would be in line with the needs of the community. With the needs of transformation, these workers should complete the continuing education according to the new teaching materials.

\section{B. Vocational Educations and the Reproduction of Reserve Labor Force}

With the deepening of urbanization in China, the original dual economic structure that existed for many years has been gradually transformed into monistic economic structure. The gap between urban and rural areas is gradually decreasing. Rural labor forces directly enter the cities to participate in urban construction and industrial production. However, the rural labor force would generally have vocational education before being employed in urban area. Vocational education system in China includes secondary vocational education, higher vocational education and undergraduate education. Teachers in vocational education are quite different from those in general education. More than $80 \%$ of teachers in 
secondary vocational schools, higher vocational colleges and vocational undergraduate schools haven't had secondary vocational education, higher vocational education and professional vocational education. These teachers often come from general undergraduates, master students and doctoral students. And the teachers who have not been influenced by vocational education would teach vocational education. This is the status of teachers of vocational education in China. However, due to the great importance attached by Chinese government and educational authorities, in recent years, many training equipment funds have been appropriated for the establishment of vocational schools. This is basically an appropriation of 10 million yuan for professional projects. If teachers who have not gone through vocational education purchase the required training equipment, the equipment wouldn't meet the actual needs. And the colleges purchase the equipment. There are a few problems. First, the colleges don't have enough places to store this equipment. Also, the colleges may don't reach the storage conditions. Second, the equipment is too expensive. The leaders of the school and the department don't want the students and the teachers to use this equipment. The training equipment purchased with much money has become to the furnishings visit by the leadership, peers, teachers and students. The training equipment directly becomes cognitive device. With the increasing ages of equipment depreciation and the update needs, the use of these devices disappears. Third, the standard of vocational education needs to be established. There is no standard. And there will have discrepancies in the decision-making of academic committees, the appraisal of professional titles committees, the selection of practical training equipment, the construction of curriculum, and the professional construction. There would have the differences in the training of teachers. Finally, it would lead to different qualifications of the same job postings through the reserve reproductive vocational education. If there is a standard, the reserve reproduction workforce would stand at the same starting line with the same professional training. And the enterprise production will be at a new level.

\section{THE REPRODUCTION OF LABOR FORCE OF "IDEOLOGICAL AND PolitiCAL EdUCATION Plus"}

With the vocational education in China, it mainly cultivates socialist qualified workers. The important consideration is to train every worker through vocational education. And these workers must be labor force with socialist morality. In order to achieve this consideration, China has tailored the course system of ideological and moral education for the students in universities and vocational colleges. First, it is ideological and moral cultivation and legal basis. Second, it is an Introduction to Maoism and Theoretical System of Socialism with Chinese Characteristics. Third, it is the situation and policy. With the newly-added theory of socialism with Chinese characteristics by $\mathrm{Xi}$ Jinping in the 19th National Congress of the Communist Party, our new generation of workers must possess the following qualities:

- To arm the mind with Xi Jinping's socialism with Chinese characteristics in a new era;
- To firmly believe that the socialist road is the most suitable path for China's development;

- To firmly believe that the Chinese Communist Party can lead the Chinese people to have the prosperity;

- To firmly believe in the leadership of the Party Central Committee with Comrade Xi Jinping as the core;

- To abide the law, respect the old and cherish the young;

- To have the patriotism, love and dedication.

Vocational education in China has marked the reserve labor force with the label of socialist workers. And they will first become new generation of people with communist beliefs. Then, they can learn various cultures, technologies and skills. In the process of labor reproduction, each of reserve laborers has their own beliefs. They firmly believe in their own beliefs. And then, they could find the right direction of learning and work. The work enthusiasm of faithful workers will be greatly released. And the productive forces of society will be extremely improved.

\section{THE REPRODUCTION OF LABOR FORCE OF "INTERNET PLUS"}

Labor reproduction can't be separated from consumption data. "Internet $+"$, modern means of payment and credit mechanisms can help re-employ workers and family members to consume consumption information and solve their problems such as clothing, food, housing, transportation and health insurance, education for children, and their own continuing education.

It should develop Apps and online shopping centers that include apparel manufacturers nationwide and even in the world to facilitate the procurement throughout the country for the labors. At the same time, it would facilitate the government to control manufacturers' price. Also, it would meet the basic needs of the workforce. At the same time, the government encourages the factory to make personalize clothing to meet the individual needs of workers nationwide.

We could develop online and offline food supply system that enriches the supply of vegetables, meat, eggs and various types of daily necessities.

We should develop housing network platform, APP platform, WeChat housing mall nationally and locally. The government should introduce local housing supply map to facilitate the purchase and rental needs for the workers. And the workers would get the first-hand housing geographic distribution map, price list, second-hand housing details and the affordable housing, low-cost housing availability and policies introduced by the government at the first time. Also, we should increase the transparency of house. It should ensure that the houses are used to living. These housed are not used to speculation.

The government should encourage the sharing of housing and transport. They could put forward the concept of sharing 
house, sharing bicycles, sharing cars, sharing books and sharing clothing.

It would make full use of medical resources, social security resources, educational resources and endowment resources through "Internet $+"$. The colleges should increase the development of micro-course resources and MOOC resources of school education and continuing education through online platforms. And it would lay good foundation of their expertise for workers and reserve labors. Then, it would constantly update the professional curriculum and skills training resources.

\section{THE REPRODUCTION OF THE LABOR OF "STANDARD PLUS"}

In order to get the best order, we should set the standards. A normative document has been developed and approved. And then, we could use and reused this normative document. "Table I"

TABLE I. THE STANDARD ClASSIFICATION

\begin{tabular}{|l|l|l|l|l|l|l|}
\hline \multicolumn{1}{|c|}{ Classification signs } & Standard & Standard & Standard & Standard & Standard & Standard \\
\hline $\begin{array}{l}\text { Divided by the scope of } \\
\text { use }\end{array}$ & $\begin{array}{l}\text { international } \\
\text { standard }\end{array}$ & $\begin{array}{l}\text { regional } \\
\text { standard }\end{array}$ & $\begin{array}{l}\text { national } \\
\text { standard }\end{array}$ & $\begin{array}{l}\text { professional } \\
\text { standard }\end{array}$ & $\begin{array}{l}\text { provincial } \\
\text { standard }\end{array}$ & $\begin{array}{l}\text { enterprise } \\
\text { standard }\end{array}$ \\
\hline Divided by the content & basic standard & $\begin{array}{l}\text { product } \\
\text { standard } \\
\text { standard } \\
\text { product } \\
\text { standard }\end{array}$ & $\begin{array}{l}\text { Auxiliary } \\
\text { standard }\end{array}$ \\
\hline Divided by maturity & $\begin{array}{l}\text { mandatory } \\
\text { standard }\end{array}$ & $\begin{array}{l}\text { recommended } \\
\text { standard }\end{array}$ & $\begin{array}{l}\text { tentative } \\
\text { standard }\end{array}$ & draft standard & \\
\hline
\end{tabular}

In order to standardize the role of the stock reproduction labor force in social production, we should formulate corresponding standards, work process standards, product process standards, qualified product standards, operation standards, raw material standards, supporting material standards and auxiliary product standards for the stock reproduction workforce. Stock reproduction workforce would upgrade their own majors and have continuing education with these standards.

Incremental reproductive labor and reserve reproductive labor should have the learning with the standards. And then, it may ensure employers' consideration of the workforce provided by the colleges.

From the perspective of human beings, there should have entrance standard, graduation standard, employment standard, teaching standard, training standard and management standard.

In term of the hardware, the colleges should set some standards. And these standards would include the standard of living area per student, the area of living quarters per student, the standard of living medical resource per student, the standard of living canteen per student, the standard of campus safety, the standard of campus life, the standard of training equipment for students, military training standards, standardization of library resources, supporting facility standards, network usage standards and son on.

In term of the connotation construction of the colleges, the established standards include the standard of professional personnel training programs, teaching program standards, teaching design standards, curriculum standards, student skill standards and post standards of labor force.

In the process of the reproduction of labor force, we should follow the standards. The labor forces we shaped are standard professional personnel. They work in accordance with the standards. With standard equipment and means of production, they would have social production. And then, they would produce standard products. Finally, it would meet the needs of the people.

\section{SIMPLE LABOR, COMPLEX LABOR AND THE REPRODUCTION OF LABOR FORCE}

Simple labor refers to manual labor of general workers who do not have technical expertise, knowledge and skills training under certain social conditions. Complicated work refers to the work that needs certain technical expertise after being trained.

Complicated work is much times as much as simple work. In the new era of socialism with Chinese characteristics, training costs for complicated labor are borne jointly by the state and the family. Therefore, the achievements of labor reproduction should be shared by the state, the family and the workers.

Expenditure on maintaining labor reproduction is called the cost of the reproduction of labor force. The total of the value of various physical materials that support the physical and mental recovery of laborers to be normally involved in socialized mass production is called the cost of simple reproduction of labor forces. And it includes the basic necessities of life and medical expenses. It is the retribution for the simple labor. The total of the value of laborers' support for their families, the production and training of household reserve labor resources and the variety of products and services necessary to enhance the technical quality and quality of their own workmanship can be called the cost of the expansion of the reproduction of labor. And it can be used as the retribution for the complicated work.

Socialism with Chinese Characteristics in the new era wants to build a well-off society in an all-round way and common prosperity of all people. Therefore, the state should raise the income of the low-income groups, expand the proportion of the middle-income groups and reduce or control the income of the high-income groups. In other words, the state subsidies the simple labors in terms of skill level and proficiency with the rewards. Also, the state adds an increment to the cost of simple reproduction of the labor force. At the same time, the state participates in the distribution of the retribution of complicated labor. The state 
would recover part of the costs of reproduction and expansion of complex labor. The cost would be used to compensate for the state's efforts in training these complex workers. Then, the state could control the incomes of the high-income groups.

In term of the colleges, teachers who are newly recruited are simple laborers. With the increase of seniority, professional titles and the amount of training attended, the complicated work continues to be formed. Teachers with higher titles have higher incomes. However, the proportion of income of complicated laborers and simple laborers is controlled by the state. It would ensure that there will be no disparity between the professors' monthly income. And in the early Republic of China, the income of professor was 500 silver dollars. The average monthly income of teacher was 8 silver dollars.

\section{VIII. "3D PRINTING" AND THE REPRODUCTION OF LABOR FORCE}

3D printing technology would bring technological revolution to all kinds of manufacturing. The manufacturing methods are changed from the past methods such as equivalent manufacturing and subtractive manufacturing to increasing manufacturing, equivalent manufacturing and subtractive manufacturing. And it has changed the traditional manufacturing methods. $3 \mathrm{D}$ printing brings great changes to the labor force. In the customization field, it would prefer to the method of 3D printing. Even small-batch production would use $3 \mathrm{D}$ printing. The labor forces who master the traditional production methods of personalized products would have the challenges. The workers are trained to master the 3D printing technology. Then, the workforce can be reappointment. And the workers who are not suited will face the transfer and re-employment. The reproductive laborers who are studying manufacturing in schools need to learn additional courses such as smart manufacturing and 3D printing.

3D printing is divided into three major classes of learning: product design and computer control systems, engineering automation and control and the development and application of print materials.

For the reproduction of labor force, 3D printing breaks the traditional thinking frame of human beings, and sets up three-dimension concept of product design and production. It opens up an unknown blueprint for the needs of society, and opens up three-dimension or multi-dimension wisdom to reproduce the labor force. The invention creates many unprecedented products. Combined with "Internet +", we can share the management and production of high-quality 3D printer all over the world with the world-wide maker and geek. Wherever conditions permit, intelligent manufacturing centers can be built to bring all types of high-quality equipment, including additive manufacturing (3D printing) equipment and reducing material manufacturing equipment (such as five-axis CNC machining equipment) and postprocessing equipment. It should build processing center of manufacturing city. It provides processing services for the maker and industry of entire city. And then, we would build the national and global intelligent manufacturing network platform through the construction platform of "Internet + ". With smart manufacturing, reproductive workforce of 3D printing training will certainly release the amazing wisdom, and dedicate unprecedented means of production and consumption data to the human beings.

\section{CONCLUSION}

In the new era of socialism with Chinese characteristics, we are working hard to practice two great projects of "one hundred years". In the new era, the reproduction of manpower must realize the all-round development of mankind. Therefore, we need to have ideological and political education. The will of workers in society should be in line with the goal of all workers. On this basis, we should provide opportunities for the workforce, and fully recognize the importance of complex workforce for the growth of the workforce. The workers should fulfill "Internet +", "Standard $+"$ and "3D Printing +". They should shape themselves into high-tech and high-wisdom workers with communist beliefs.

\section{REFERENCES}

[1] Karl Marx. Capital Theory [M]. People's Publishing House, 1975.

[2] Tao Fuyuan, Jin Cheng. The basic connotation of human development [J]. Journal of Gannan Normal University, 2004(2).

[3] GB/T 20000. 1-2002 " Guide for Standardization-Part 6:Code of Good Practice for Standardization " 